\title{
AKTIVITAS HIPOLIPIDEMIK EKSTRAK ETANOL HERBA KROKOT (Portulaca oleracea L.) PADA TIKUS OBESITAS DENGAN PARAMETER TRIGLISERIDA
}

\author{
Rizqi Nur Azizah, Bayu Putra, Rafika Tobis
}

Fakultas Farmasi Universitas Muslim Indonesia, Makassar

Email : rizqi.azizah@umi.ac.id

\begin{abstract}
Hypolipidemics a drug used to lower plasma lipid levels in the blood. This study aimed to examine the hypolipidemic activity of ethanol extract of purslane herb (Portulaca oleracea L.) against the triglyceride level reduction in obese mice. The purslane herb contains omega-3, flavonoids and hight ascorbic acid as a lowering of triglyceride levels in the blood. This study used 15 malerats divided into 5 groups. Group I (negative control) was given Na.CMC 1\%, group II (positive control) was given Gemfibrozil, group III, IV, and $V$ were given ethanol extract of purslane herb with dose of $100 \mathrm{mg} / \mathrm{kgBW}, 200 \mathrm{mg} / \mathrm{kgBW}$, and $300 \mathrm{mg} / \mathrm{kgBW}$ as therapy group. All the administration were done orally once a day for 16 days. The measurement of triglyceride level was performed on early triglycerides before induction, after induction and after therapy. Before therapy, the rats were given hight-calorie diet. The results showed that the ethanol extract of purslanes herb has activity as hypolipidemic in lowering trygliseride level in obese mice. From the statistic result of One-Way ANOVA followed by LSD test, it can be concluded that the ethanol extract of purslane herb of the dose $100 \mathrm{mg} / \mathrm{kgBW}$ provide the most effective hypolipidemic activity that triglyceride level is not significantly different from positive control group $(p>0,05)$.
\end{abstract}

Key words : Hypolipidemic, purslane herb (Portulaca oleracea L.), triglycerides.

\section{PENDAHULUAN}

Trigliserida adalah bentuk lemak yang paling efisien untuk menyimpan kalori yang penting untuk prosesproses yang membutuhkan energi dalam tubuh. Trigliserida banyak didapatkan dalam sel-sel lemak; terutama $99 \%$ dari volume sel. ${ }^{1}$ Trigliserida diangkut terutama sebagai kilomikron dari usus menuju hati, kemudian mengalami metabolisme di hati dan dalam jumlah yang besar sebagai VLDL diangkut dari hati menuju ke seluruh jaringan tubuh. Oleh 
Aktivitas hipolipidemik ekstrak etanol herba krokot (Portulaca oleracea L.) pada tikus obesitas dengan parameter trigliserida

karena itu trigliserida yang tinggi cenderung disertai dengan VLDL dan LDL yang tinggi pula, sementara HDL justru rendah. ${ }^{2}$ Berlebihnya kadar trigliserida di dalam darah dapat menyebabkan munculnya berbagai penyakit seperti hiperlipidemia yang mengakibatkan aterosklerosis, dislipedemia, jantung koroner, dan penyakit jantung iskhemik.

Salah satu tanaman obat yang dinyatakan sebagai hipolipidemik yaitu krokot (Portulaca oleraceae L.) yang berperan untuk menurunkan total kolesterol, trigliserida, LDL (low densitiy lipoprotein) dan meningkatkan HDL (hight density lipoprotein). ${ }^{3}$

Anggarani et al (2013), telah melaporkan penelitian tahun 2012 oleh Kevin dan Kurniadi yang menyatakan bahwa krokot di identifikasi sebagai sumber yang sangat baik dari asam alpha-linolenat. ${ }^{4}$ Alpha-linolenat adalah asam lemak omega-3 yang juga dikenal sebagai minyak ikan. Omega-3 sangat penting dalam krokot herbal yang berperan dalam pertumbuhan manusia, pembangunan dan pencegahan penyakit.

Berdasarkan dari penjelasan diatas tujuan dilakukannya penelitian ini yaitu untuk menguji aktivitas hipolipidemik dari ekstrak etanol herba krokot (Portulaca oleracea L.) pada tikus obesitsas dengan parameter trigliserida.

\section{METODE PENELITIAN}

Penelitian ini menggunakan 15 ekor tikus yang dibagi dalam 5 kelompok, yaitu kelompok I sebagai kontrol negatif (Na.CMC), kelompok II sebagai kontrol positif (Gemfibrozil), dan kelompok III, IV, dan V yang diberi ekstrak etanol herba krokot (Portulaca oleracea $L$.) dengan dosis berturut-turut $100 \mathrm{mg} / \mathrm{kgBB}, 200 \mathrm{mg} / \mathrm{kgBB}$, dan 300 $\mathrm{mg} / \mathrm{kgBB}$. Induksi obesitas dilakukan dengan pemberian diet tinggi kalori. ${ }^{5}$

\section{Bahan dan Alat}

Adapun bahan-bahan yang digunakan dalam penelitian ini, yaitu aquades, etanol 96\%, diet tinggi kalori, herba krokot (Portulaca oleracea L.), natrium karboksimetilselulosa (Na. $\mathrm{CMC}$ ), reagen pengujian trigliserida (Triglyserides Mono SL New), dan gemfibrozil. Alat-alat yang digunakan dalam penelitian ini, yaitu seperangkat alat kaca, Human Analyzer (Microlab 300), mikropipet (original eppendorf), sentrifuge, spoit dan vortex (Mixer).

\section{Prosedur Kerja}

\section{Pembuatan ekstrak etanol herba krokot (Portulaca oleracea L.)}

Serbuk simplisia herba krokot (Portulaca oleracea L.) ditimbang 500 g, lalu dimaserasi. Simplisia direndam selama 6 jam pertama sambil diaduk 
Aktivitas hipolipidemik ekstrak etanol herba krokot (Portulaca oleracea L.) pada tikus obesitas dengan parameter trigliserida

sekali-kali, kemudiam didiamkan diperoleh dipekatkan dengan selama 18 jam. Dipisahkan maserat menggunakan rotavapor hingga dari residu dengan cara filtrasi atau diperoleh ekstrak etanol kental. ${ }^{6}$ penyaringan. Hasil penyarian yang

\section{Pembuatan pakan diet tinggi kalori}

Tabel 1. Komposisi diet tinggi kalori untuk tiap $1 \mathrm{~kg}$ pakan ${ }^{7}$

\begin{tabular}{cc}
\hline Bahan & Diet Tinggi Kalori $\mathbf{( g / k g )}$ \\
\hline Tepung beras & 300 \\
Tepung jagung & 200 \\
Tepung ikan & 100 \\
Tepung kacang hijau & 100 \\
Tepung gandum & 150 \\
Lemak sapi & 200 \\
\hline
\end{tabular}

Pembuatan suspensi Gemfibrozil $80,330 \mathrm{mg} / \mathrm{kgBB}$

Tablet Gemfibrozil $300 \mathrm{mg}$ ditimbang sebanyak 20 tablet dan ditimbang yang setara dengan $80,330 \mathrm{mg} / 10 \mathrm{~mL}$, lalu disuspensikan dengan $\mathrm{Na}$. CMC $1 \% \mathrm{~b} / \mathrm{v}$ hingga 10 $\mathrm{mL}{ }^{8}$

\section{Pembuatan suspensi ekstrak etanol} herba krokot (Portulaca oleracea L.)

Suspensi ekstrak etanol herba krokot (Portulaca oleracea L.) dibuat dengan menimbang masing-masing ekstrak sebanyak 100 mg, 200 mg, dan $300 \mathrm{mg}$, kemudian masing-masing ekstrak disuspensikan dengan $10 \mathrm{~mL}$ Na.CMC $1 \%$ b/v. ${ }^{8}$

\section{Perlakuan Hewan Uji}

Dilakukan pengambilan darah untuk pengukuran kadar trigliserida tikus (kadar trigliserida awal). Kemudian, tikus diberikan pakan diet tinggi kalori selama 30 hari berturutturut. Setelah itu dilakukan pengukuran kadar trigliserida tikus (kadar trigliserida induksi). Kemudian dilakukan perlakuan terapi pada tikus obesitas dilakukan secara oral selama 16 hari. Pada hari ke 17 setelah pemberian perlakuan terapi, dilakukan pengukuran kadar trigliserida pada tikus (kadar trigliserida akhir). ${ }^{5}$

\section{Pengambilan sampel darah hewan} uji

Ekor tikus dijulurkan, kemudian vena lateralis pada ekor tikus dipotong $0,2 \mathrm{~cm}$ dari ujung ekor menggunakan gunting steril. Darah ditampung pada tabung eppendorf sebanyak $1 \mathrm{~mL}$, kemudian disentrifugasi selama 10 menit dengan kecepatan $3.000 \mathrm{rpm}$, lalu diambil serumnya (lapisan bening) ${ }^{9}$ 
Aktivitas hipolipidemik ekstrak etanol herba krokot (Portulaca oleracea L.) pada tikus obesitas dengan parameter trigliserida

Pengukuran kadar trigliserida hewan uji

Serum darah sebanyak $3 \mu \mathrm{L}$ trigliserida, kemudian divortex dan dimasukkan dalam Human Analyzer untuk diukur kadar trigliseridanya. ${ }^{10}$ ditambahkan $300 \mu \mathrm{L}$ reagen

\section{HASIL PENELITIAN}

Tabel 2. Analisis rata-rata pengukuran kadar trigliserida awal, induksi dan terapi pada tikus obesitas.

\begin{tabular}{ccccc}
\hline Kelompok & Awal \pm SD & Induksi \pm SD & Terapi \pm SD & $\%$ penurunan \\
\hline Kontrol negatif & $96,33 \pm 4,61$ & $191,66 \pm 32,53$ & $261,00 \pm 81,18$ & $-41,88$ \\
Kontrol positif & $91,66 \pm 8,50$ & $166,00 \pm 14,00$ & $67,66 \pm 13,50$ & 59,38 \\
EEHK 100mg/KgBB & $90,00 \pm 8,88$ & $178,00 \pm 20,07$ & $109,66 \pm 16,28$ & 37,24 \\
EEHK 200mg/KgBB & $84,66 \pm 2,51$ & $166,00 \pm 18,02$ & $117,00 \pm 21,79$ & 27,93 \\
EEHK 300mg/KgBB & $86,33 \pm 7,57$ & $155,66 \pm 7,50$ & $132,33 \pm 23,35$ & 14,76 \\
\hline
\end{tabular}

Tabel 3. Persen penurunan kadar trigliserida induksi-terapi dari uji aktivitas hipolipidemik ekstrak etanol herba krokot (Portulaca oleracea L.) terhadap tikus obesitas.

\begin{tabular}{cc}
\hline Kelompok Perlakuan & $\begin{array}{c}\text { Persen Penurunan Kadar Trigliserida } \\
\text { (induksi-terapi) (\%) }\end{array}$ \\
\hline Kontrol Negatif & $-41,88$ \\
Kontrol Positif & 59,38 \\
EEHK 100mg/kgBB & 37,24 \\
EEHK 200mg/kgBB & 27,93 \\
EEHK 300mg/kgBB & 14,76 \\
\hline
\end{tabular}

\section{PEMBAHASAN}

Penelitian ini bertujuan untuk menguji aktivitas hipolipidemik ekstrak etanol herba krokot (Portulaca oleracea L.) pada tikus obesitas dengan parameter trigliserida. Sampel yang diujikan yaitu ekstrak etanol herba krokot (Portulaca oleracea L.) yang diekstraksi dengan metode maserasi menggunakan pelarut etanol 96\%.
Dosis yang digunakan yaitu 100 $\mathrm{mg} / \mathrm{kgBB}, 200$ mg/kgBB dan 300 $\mathrm{mg} / \mathrm{kgBB}$.

Pada kelompok kontrol negatif mengalami kenaikan kadar trigliserida, artinya Na.CMC tidak memiliki efek untuk menurunkan trigliserida. Terjadi penurunan kadar trigliserida untuk kelompok kontrol positif (gemfibrozil), karena gemfibrozil merupakan salah 
Aktivitas hipolipidemik ekstrak etanol herba krokot (Portulaca oleracea L.) pada tikus obesitas dengan parameter trigliserida

satu obat yang dapat menurunkan kadar trigliserida dalam darah dengan baik. Gemfibrozil bekerja sebagai ligan untuk reseptor transkripsi nukleus, reseptor alfa peroksisom yang diaktivasi proliferator (PPAR- $\alpha$, peroxisome proliferator-activated reseptor alpha) dan menstimulasi aktivitas lipoprotein lipase. ${ }^{11}$

Pada tabel 3 terlihat semua kelompok kecuali kelompok kontrol negatif $(-41,88 \%)$, mengalami penurunan kadar trigliserida yaitu EEHK $\quad 100 \mathrm{mg} / \mathrm{kgBB}$ mengalami penurunan 37,24\%, EEHK 200 $\mathrm{mg} / \mathrm{kgBB}$ mengalami penuruan $37,24 \%$ dan EEHK $300 \mathrm{mg} / \mathrm{kgBB}$ mengalami penurunan $14,76 \%$,

Dari hasil analisis statistik dapat diketahui bahwa semua kelompok perlakuan ekstrak memiliki efektivitas dalam menurunkan kadar trigliserida pada tikus obesitas. Sedangkan jika dilihat dari persen penurunan, efek hipolipidemik yang paling baik terdapat pada EEHK $100 \mathrm{mg} / \mathrm{kgBB}$ yaitu $37,24 \%$ mendekati persen penurunan kadar trigliserida kelompok kontrol positif (gemfibrozil) yaitu 59,38\%, dibandingkan dengan kelompok EEHK $200 \mathrm{mg} / \mathrm{kgBB}$ (27,93\%) dan EEHK $300 \mathrm{mg} / \mathrm{kgBB}(14,76 \%)$.

Hasil penelitian ini sejalan dengan penelitian yang telah dilakukan
Samah Ali El-Newary yang menyatakan bahwa herba krokot memiliki efek hipolipidemik terhadap penurunan kadar trigliserida. $^{3}$ Dan pada penelitian yang telah dilakukan Ashtiyani, penurunan kadar trigliserida yang paling baik terdapat pada efek minimum dari dosis yang digunakan (200 mg/kgBB, $\quad 400 \mathrm{mg} / \mathrm{kgBB}$ dan $800 \mathrm{mg} / \mathrm{kgBB}$ ) dibandingkan dengan hasil penelitian yang telah di dapatkan, yaitu efek paling baik untuk menurunkan kadar trigliserida adalah $100 \mathrm{mg} / \mathrm{kgBB}$ dari perbandingan dosis yang telah digunakan $(100 \mathrm{mg} / \mathrm{kgBB}$, $200 \mathrm{mg} / \mathrm{kgBB}$ dan $300 \mathrm{mg} / \mathrm{kgBB}$ ) dibawah dari dosis $200 \mathrm{mg} / \mathrm{kgBB}$, walaupun begitu belum diketahui jelas dosis terendah dari herba krokot (Portulaca oleracea L.) yang dapat menurunkan kadar trigliserida yang paling baik. ${ }^{5}$

Hasil penelitian menunjukkan bahwa dosis rendah memberikan efektifitas lebih baik daripada dosis tinggi hal ini dipengaruhi oleh keberadaan zat "ballast" didalam tanaman. Zat "ballast" adalah kandungan kimia yang umumnya terdapat pada tanaman seperti lemak, karbohidrat, protein, klorofil dan resin. ${ }^{12}$ Adanya zat ballast ini memiliki peran yang besar dalam menimbulkan efek farmakologis, dapat berupa membantu 
Aktivitas hipolipidemik ekstrak etanol herba krokot (Portulaca oleracea L.) pada tikus obesitas dengan parameter trigliserida

kelarutan, membantu proses absorbsi, menghambat atau meningkatkan efek. Pada dosis rendah zat "ballast" yang terkandung dalam ekstrak lebih sedikit dibandingkan dengan ekstrak dosis tinggi, sehingga efek yang ditimbulkan akan semakin baik jika dibandingkan dengan ekstrak dengan dosis tinggi yang mengandung zat ballast yang lebih banyak.

Penurunan kadar trigliserida diduga karena ekstrak etanol herba krokot (Portulaca oleracea L.) sebagai hipolipidemik yang mengandung omega-3, flavanoid dan asam askorbat yang berkhasiat sebagai hipolipidemik untuk menurunkan kadar trigliserida. ${ }^{3,5}$

Pada dasarnya kandungan ekstrak etanol herba krokot yaitu asam lemak omega-3 akan menekan sintesis trigliserida dalam hati, dengan sendirinya menekan VLDL dalam plasma, omega-3 mempengaruhi lipolisis jaringan lemak, sehingga trigliserida tidak terbentuk melalui reaksi asam lemak bebas dengan gliserol. ${ }^{13}$

Flavanoid memiliki kemampuan menangkal radikal bebas berlebih yang dihasilkan oleh sintesa asam empedu sehingga dapat meningkatkan aktivitas lipoprotein lipase karena terjadinya peroksidasi lipid dapat dihambat oleh flavonoid yang bersifat sebagai antioksidan. Peningkatan aktivitas enzim lipoprotein lipase akan menghidrolisis trigliserida menjadi asam lemak bebas dan gliserol yang kemudian dapat disimpan dalam jaringan adipose dan jaringan otoT. ${ }^{14}$

Asam askorbat sebagai antioksidan berfungsi menangkap radikal peroksil sehingga dapat melindungi LDL dari kerusakan oksidatif, memfasilitasi penyerapan VLDL dan meningkatkan ekskresi VLDL dari plasma sehingga dapat menurunkan kadar trigliserida dalam darah. Asam askorbat dapat menurunkan kadar trigliserida dalam darah tetapi tidak berlaku pada orang dengan kadar trigliserida normal, ini menunjukkan peran asam askorbat dalam menjaga kesimbangan tubuh yang baik (homeostatis). ${ }^{15}$

\section{KESIMPULAN}

Berdasarkan penelitian yang dilakukan dapat disimpulkan bahwa ekstrak etanol herba krokot (Portulaca oleracea L.) memiliki aktivitas terhadap penurunan kadar trigliserida tikus obesitas sebagai hipolipidemik. ekstrak etanol herba krokot (Portulaca oleracea L.) yang memiliki aktivitas paling baik terhadap penurunan kadar trigliserida tikus obesitas adalah dosis 100 $\mathrm{mg} / \mathrm{kgBB}$ yaitu $p>0,05$ dengan persen penurunan $37,24 \%$. 


\section{DAFTAR PUSTAKA}

1. Soeharto. Penyakit Jantung Koroner. Jakarta : PT. Gramedia, 2000.

2. Goodman and Gilman. The Pharmacological Basic of Therapeutics. Bandung: Sekolah Farmasi ITB. EGC, 2001.

3. El-Newary SA. The Hipolipidemic effect of Portulaca oleraceae L. stem on hyperlipidemic Wister Albino Rats. Analysis of Agricultural Science. 2016;61(1):111-112.

4. Anggarani ND. Table Kroasia ; Tablet Krokot Berkhasiat, Inovasi Effervescent dari Tanaman Krokot (Portulaca oleraceae L.) sebagai Alternatif Minuman Bersuplemen Bagi Penderita Radang Usus Buntu. Jurnal IImiah Mahasiswa. 2012;2(2):92-93.

5. Ashtiyani, Zarei A, Taheri S, Rasekh $F$, Ramazan M. The Effects of Portulaca Oleraceae Alcoholic Extract on Induced Hypercholestroleomia in Rats. Zahedan Journal of Research in Medical Sciences.2012;15(6):3438.

6. Kementerian Kesehatan $R$. Suplemen farmakope herbal Indonesia. Jakarta, 2010.

7. Abuzaid AS, Sukandar EY, Kurniati NF, Adnyana IK. Preventive Effect on Obesity of Mangosteen (Garcinia Mangostana L.) Pericarp Ethanolic Extract by Reduction of Fatty Acid Synthase Level in Monosodium Glutamate and High-Calorie DietInduced Male Wistar Rats. Asian Journal of Pharmaceutical and Clinical Research. 2016;9:257-260.
8. Nurtina WO. Uji Efektivitas Kombinasi Ekstrak Etanol Daun Jambu Biji (Psidium guajava Linn) dengan Daun Salam (Syzygium polyanthum) terhadap Penurunan Kadar Kolesterol pada Tikus Hiperlipidemia (Skripsi). Makassar: Fakultas Farmasi, Universitas Muslim Indonesia, 2016.

9. Cahyani I. Perbandingan Penurunan Kadar Kolesterol Tikus Putih (Rattus norvegicus) Setelah Pemberian Ekstrak Etanol dan Etil Asetat Daun Sukun (Arthocarpus altilis) (Skripsi). Makassar : Fakultas Farmasi, Universitas Muslim Indonesia, 2016.

10. Rahmawati. Uji Efektivitas Kombinasi Ekstrak Etanol Daun Jambu Biji (Psidium guajava Linn) dengan Daun Salam (Syzygium polyanthum) terhadap Penurunan Kadar Trigliserida pada Tikus Hiperlipidemia (Skripsi). Makassar : Fakultas Farmasi, Universitas Muslim Indonesia, 2016.

11. Neal, Michael. At Glance Farmakologi Medis Edisi 5. Jakarta : Penerbit Erlangga, 2006.

12. Pramono, Suwijiyo. Kontribusi Bahan Obat Alam Dalam Mengatasi Krisis Bahan Obat Di Indonesia. Yogyakarta : Fakultas Farmasi Universitas Gadjah Mada, 2002.

13. Duthie IF, Barlow SM., Dietary lipid exemplified by fish oils and their n-3 facid acid. Food Sci Technol. 1992;6:20-35.

14. Packer L, Cadenas E. Handbook of Antioxidant $2^{\text {nd }}$ Edition, New York: Marcel Dekker Inc., 2001. 
Aktivitas hipolipidemik ekstrak etanol herba krokot (Portulaca oleracea L.) pada tikus obesitas dengan parameter trigliserida

15. Afkhami-Ardekani M, ShojaoddinyArkedekani Ahmad. Effect of Vitamin C on blood Glucose, Serum Lipid and Serum Insulinin Type 2
Diabetes Patients. Iran : Diabetes Research Center, Shahid Sadoughi University of medical Science and Health Services, Yazd, 2006. 